\title{
The Role of Phosphate in the Action of
}

\section{Vitamin D on the Intestine}

\author{
Stanley J. Birge and Ruth Miller, Department of Medicine, Division \\ of Endocrinology and Metabolism, Washington University School of \\ Medicine, The Jewish Hospital of St. Louis, St. Louis, Missouri 63110
}

A B S T RACT The response of chick intestine to vitamin D and its metabolites was studied in an organ culture preparation of chick ileum explants. Both 25hydroxycholecalciferol $\left(25-\mathrm{OHD}_{3}\right)$ at a concentration of $20 \mathrm{ng} / \mathrm{ml}$ or greater and 1,25-dihydroxycholecalciferol $\left[1,25-(\mathrm{OH})_{2} \mathrm{D}_{3}\right]$ at a concentration of $50 \mathrm{pg} / \mathrm{ml}$ or greater stimulated the rate of accumulation of $\left[{ }^{32} \mathrm{P}\right]$ phosphate and ${ }^{45} \mathrm{Ca}$ by the explants and the incorporation of $\left[{ }^{3} \mathrm{H}\right]$ thymidine into DNA. The accumulation of $\left[{ }^{32} \mathrm{P}\right]-$ phosphate by the explants was against a concentration gradient and inhibited by ouabain and dinitrophenol. Two saturable mechanisms appeared to mediate the cellular accumulation of phosphate with $K_{a}$ of 0.0047 and 0.125 $\mathrm{mM}$, respectively. The $V_{\max }$ of the lower affinity transport mechanism was accelerated by $1,25-(\mathrm{OH})_{2} \mathrm{D}_{3}$. Actinomycin $\mathrm{D}(5.0 \mu \mathrm{g} / \mathrm{ml})$ did not block the intestinal response to $1,25-(\mathrm{OH})_{2} \mathrm{D}_{3}$ stimulation of both [ $\left.{ }^{32} \mathrm{p}\right]$ phosphate and ${ }^{45} \mathrm{Ca}$ accumulation. Significant stimulation of $\left.{ }^{32} \mathrm{P}\right]$ phosphate accumulation was observed $30 \mathrm{~min}$ after the addition of $1,25-(\mathrm{OH})_{2} \mathrm{D}_{3}$, preceding the sterol-induced increase in the rate of ${ }^{45} \mathrm{Ca}$ uptake by $30 \mathrm{~min}$ and the sterol-induced increase in $\left[{ }^{3} \mathrm{H}\right]-$ thymidine incorporation into DNA by $150 \mathrm{~min}$. Increasing extracellular phosphate concentration to 3.0 $\mathrm{mM}$ increased $\left[{ }^{3} \mathrm{H}\right]$ thymidine incorporation into DNA and the rate of ${ }^{45} \mathrm{Ca}$ uptake by the explants. Reducing extracellular phosphate concentration to $0.05 \mathrm{mM}$ attenuated the response of the explants to $1,25-(\mathrm{OH})$ ${ }_{2} \mathrm{D}_{3}$. From these observations it is postulated that the primary action of vitamin $\mathrm{D}$ sterols in the intestine is to enhance the ability of the mucosal cell to accumulate phosphate. The data suggest that restoration of intracellular phosphate levels may then permit expression of the cells' response to vitamin D sterols.

This work was presented, in part, at the Annual Meeting of The Central Society, Chicago, Ill., November, 1976.

Dr. Birge is a recipient of a National Institutes of Health Career Development Award.

Received for publication 9 February 1977 and in revised form 3 June 1977.

\section{INTRODUCTION}

Hypophosphatemia is a prominent feature of the vitamin $\mathrm{D}$ deficiency and vitamin D-resistant states. Recent investigations have led to the recognition that the restoration of phosphate homeostasis in the rachitic animal is the consequence of the direct action of vitamin $\mathrm{D}$ on a variety of tissues. These investigations have demonstrated that vitamin D stimulates the absorption of phosphate by the intestine (1-6), the mobilization of phosphate from bone (7) and from possibly other tissue stores (8), and enhances the reabsorption of phosphate by the renal tubule (8-11). Synthesis of the active metabolite of vitamin D, 1,25dihydroxycholecalciferol $\left[1,25-(\mathrm{OH})_{2} \mathrm{D}_{3}\right]^{1}$ is under the direct control of the plasma phosphate concentration $(12,13)$. Thus, a feedback control mechanism exists for the regulation of plasma phosphate levels by vitamin D. From these observations it is apparent that vitamin D is an important determinant of phosphate balance by influencing phosphate transport at multiple tissue sites.

Another aspect of vitamin D action is the maintenance of normal growth. Growth retardation, characteristic of vitamin $\mathrm{D}$ deficiency, has been attributed to the deficiency of bone mineral. Indeed, the restoration of blood $\mathrm{Ca}$ and phosphorus levels through appropriate dietary supplements significantly reverses this growth retardation but never to the same extent as that achieved by the repletion of the rachitic animal with vitamin $D$ (14). The identification in essentially all tissues of a cytoplasmic protein which specifically binds 25-hydroxycholecalciferol $\left(25-\mathrm{OHD}_{3}\right)$ with high affinity $(15,16)$ suggests that vitamin $D$ may influence cellular metabolism at a nonspecific or basic level which could result in increased tissue growth. In fact, $25-\mathrm{OHD}_{3}$ has been shown to act directly on skeletal muscle in vitro to accelerate the accumulation of phos-

\footnotetext{
${ }^{1}$ Abbreviations used in this paper: 25-OHD 3 ,25-hydroxycholecalciferol; 1,25-(OH) $)_{2} \mathrm{D}_{3}, 1,25$-dihydroxycholecalciferol.
} 
phate and to subsequently stimulate the rate of protein synthesis (17). A direct influence of vitamin D on intestinal mucosal cell proliferation has also been suggested by the acceleration of DNA synthesis in intestinal epithelium which precedes significant alterations in systemic calcium and phosphorus concentrations (18).

It was the purpose of these investigations to examine the influence of vitamin D on mucosal cell proliferation and to examine the role of phosphate in the expression of the intestinal response to the vitamin. To this end, an organ culture preparation of vitamin Ddeficient chick ileum was developed which permitted control of the extracellular ionic environment. These investigations suggest that the response of the intestinal mucosa to $1,25-(\mathrm{OH})_{2} \mathrm{D}_{3}$ and $25-\mathrm{OHD}_{3}$ is dependent upon the restoration of intracellular phosphate concentrations resulting from the direct action of these sterols on the mucosal cell phosphate transport.

\section{METHODS}

Preparation of chick intestine organ culture. 1-day-old white leghorn chicks (Ken Roy, Berger, Mo.) were maintained on a vitamin D-deficient rachitogenic diet (Teklad Test Diets, Life Sci. Div., The Mogul Corp., Madison, Wis.) for $4 \mathrm{wk}$ before the removal of the intestinal segment demarcated distally by the attachment of the glands of Cowper and proximately by the yolk sac remnant. The explants were made with a 2-mm skin punch biopsy, and six explants equivalent to approximately $1 \mathrm{mg}$ protein were placed mucosal side up on glass fiber filter. The filters were supported in a Falcon organ culture dish (Falcon Plastics, Div. of BioQuest, Oxnard, Calif.) containing $1.4 \mathrm{ml}$ of medium and incubated at $37^{\circ} \mathrm{C}$ in an atmosphere of $95 \% \mathrm{O}_{2}$ and $5 \% \mathrm{CO}_{2}$. The incubation medium consisted of an Earle's buffered saline containing a final concentration of $1.4 \mathrm{mM} \mathrm{Ca}, 2.0$ $\mathrm{cm}^{3} / \mathrm{dl}$ of $50 \times$ minimal essential medium amino acid mixture, $10,000 \mathrm{U} / \mathrm{dl}$ of insulin, $30 \mathrm{mg} / \mathrm{dl}$ of glutamine, $10,000 \mathrm{U} / \mathrm{dl}$ penicillin, $10 \mathrm{mg} / \mathrm{dl}$ of steptomycin, and $2.5 \mathrm{~cm}^{3} / \mathrm{dl}$ of serum from vitamin D-deficient chicks. The vitamin D sterols were solubilized in the vitamin-deficient chick serum before their addition to the cultures. Crystalline $25-\mathrm{OHD}_{3}$ was kindly supplied by Dr. John Babcock of the Upjohn Co., Kalamazoo, Mich. The sterol was dissolved in absolute ethanol and final dilutions were aliquoted on the basis of the molar extinction coefficient. Both 25- $\mathrm{OHD}_{3}$ and $\left[{ }^{3} \mathrm{H}-26,27\right] 25-\mathrm{OHD}_{3}$ (Amersham/Searle Corp., Arlington Heights, Ill.; specific radioactivity of $1.1 \mathrm{Ci} / \mathrm{mmol}$ ) were purified on $1 \times 55-\mathrm{cm}$ columns of Sephadex LH-20 (Pharmacia Fine Chemicals, Inc. Piscataway, N. J.) slurried in chloroform-n-hexane (65:35 $\mathrm{vol} / \mathrm{vol}$ ) before use. The $1,25(\mathrm{OH})_{2} \mathrm{D}_{3}$ was synthesized from the incubation of $25-\mathrm{OHD}_{3}$ of known specific radioactivity with rachitic chick kidney homogenates as described by Boyle et al (19). The product was extracted and purified by silicic acid and Sephadex LH-20 chromatography. Phosphate salts were added to the incubation medium from a neutral stock solution to give the appropriate phosphate concentration. To achieve phosphate concentrations of less than $0.05 \mathrm{mM}$ in the medium, serum dialyzed against phosphate-free buffer was used. Data from a single experiment represent the averages of six dishes of 36 explants per group. In a single experiment, four to six groups could be conveniently studied. Since the explants were derived from a single pool for a given experi- ment, statistical significance was determined from a $t$ test of paired data analysis.

Tracer accumulation studies. The rate of DNA synthesis by the explants was estimated by measuring the incorporation of $\left[{ }^{3} \mathrm{H}\right]$ thymidine into DNA extracted from explants solubilized in $\mathrm{KOH}$. Incubations were carried out in medium containing $10 \mu \mathrm{mol}$ of thymidine/dl and $200 \mu \mathrm{Ci}$ of $\left[{ }^{3} \mathrm{H}-\right.$ methyl]thymidine/dl (New England Nuclear, Boston, Mass.) The incubations were terminated by washing the explants on their supporting filter with ice-cold buffer over vacuum, then transferring directly to $0.5 \mathrm{~N} \mathrm{KOH}$ or homogenizing in cold $5 \%$ perchloric acid. The radioactivity was measured with a liquid scintillation spectrometer and expressed as disintegrations per minute per microgram of DNA as measured by the method of Cerriotti (20) and modified by Keck (21) and Bonting and Jones (22). RNA synthesis was estimated from measurements of incorporation of $\left[{ }^{3} \mathrm{H}-5,6\right]$ uridine (New England Nuclear) into RNA. RNA was extracted in $0.3 \mathrm{~N} \mathrm{KOH}$ for $1 \mathrm{~h}$ at $37^{\circ} \mathrm{C}$ from explant homogenates by the method of Munro and Fleck (23). Total RNA was measured by ultraviolet absorption at 260 and $232 \mu \mathrm{m}(24)$.

The rate of ${ }^{45} \mathrm{Ca}$ uptake was measured by immersing the filter with explants into a 40-mM Hepes (Sigma Chemical Co., St. Louis, Mo.) buffer at $\mathrm{pH} 7.4$ containing $2 \mu \mathrm{Ci} / \mathrm{dl}$ of ${ }^{45} \mathrm{Ca}$ (New England Nuclear) for a 4 -min period. The incubation was terminated by removing the explants on their filter from the labeled buffer, then washing over a vacuum with ice-cold buffered saline, $\mathrm{pH} \mathrm{6.5}$, containing $15 \mathrm{mM} \mathrm{CaCl}_{2}$. The washed explants were then transferred promptly to 0.5 $\mathrm{N} \mathrm{KOH}$ solubilizing solution. The rate of accumulation of $\left.{ }^{32} \mathrm{P}\right]$ phosphate (New England Nuclear) was studied over a 16-min incubation in medium containing 20-200 $\mu \mathrm{Ci}$ $\left.{ }^{32} \mathrm{P}\right]$ sodium phosphate/dl. The incubation was terminated by washing the explants on their filter with ice-cold $10 \mathrm{mM}$ phosphate-buffered saline over vacuum. The explants were promptly quick frozen in dry ice in preparation for their subsequent processing for determination of total and free inorganic phosphate content as described by Lippman and Tuttle (25) and modified by Short et al. (26). Radioactivity of ${ }^{45} \mathrm{Ca}$ and ${ }^{32} \mathrm{P}$, measured by liquid scintillation spectrometry, are expressed per milligram of protein (27).

Metabolic inhibition studies. Cycloheximide (Sigma Chemical Co.) at a concentration of $50 \mu \mathrm{g} / \mathrm{ml}$ was added with $1,25-\mathrm{OH})_{2} \mathrm{D}_{3}$ and was present for the duration of the incubation with the sterol. Actinomycin D (Calbiochem, San Diego, Calif.) was added to the cultures $20 \mathrm{~min}$ before the addition of the sterol at concentrations of 0.5 and $5.0 \mu \mathrm{g} / \mathrm{ml}$. Iodoacetamide, dinitrophenol, and ouabain (Sigma Chemical Co.) were selected as inhibitors of energy-dependent transport. After the appropriate period of incubation, the explants were transferred to either fresh medium or medium containing the inhibitor for an 8-min period before the transfer of the explants to medium containing either ${ }^{45} \mathrm{Ca}$ or $\left[{ }^{32} \mathrm{P}\right]$ phosphate, with or without the inhibitor.

\section{RESULTS}

Explants of vitamin D-deficient rachitic chick ileum were maintained in organ culture to study the response of this tissue to vitamin $\mathrm{D}$ and its metabolites under controlled environmental conditions. One parameter of the tissue response to the vitamin measured was the rate of $\left[{ }^{3} \mathrm{H}\right]$ thymidine incorporation into DNA. In control explants linear rates of $\left[{ }^{3} \mathrm{H}\right]$ thymidine incorporation into DNA were observed up to $12 \mathrm{~h}$ after an initial 90-min period of equilibration (Fig. 1). Since the non- 


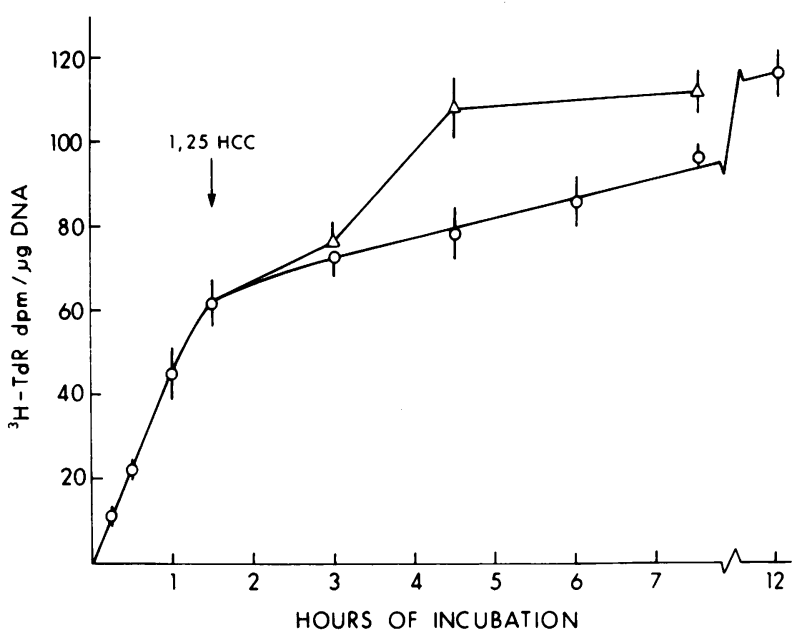

FIGURE 1 Incorporation of $\left[{ }^{3} \mathbf{H}\right]$ thymidine $\left({ }^{3} \mathrm{H}-\mathrm{TdR}\right)$ into DNA of intestinal explants from vitamin D-deficient chicks. The data are expressed as the cumulative incorporation of the label per microgram DNA from time zero. Open circles indicate the incorporation of label in the absence of 1,25 $(\mathrm{OH})_{2} \mathrm{D}_{3}$. The triangles indicate the cumulative incorporation of label into explants to which 1,25 HCC had been added after $1.5 \mathrm{~h}$ of incubation in the presence of $\left[{ }^{3} \mathrm{H}\right]$ thymidine. The vertical bars indicate the standard error of the mean.

linear characteristics of the rate of $\left[{ }^{3} \mathrm{H}\right]$ thymidine incorporation into DNA may represent saturation of an intracellular thymidine pool, the influence of vitamin $D$ metabolites on $\left[{ }^{3} \mathrm{H}\right]$ thymidine incorporation into DNA was studied after $90 \mathrm{~min}$ of preincubation with the label and linearity of incorporation of the label was achieved. In so doing, changes in the rate of transport of exogenous thymidine induced by the vitamins would be minimized. Under these conditions both $1,25-(\mathrm{OH})_{2} \mathrm{D}_{3}$ at $50 \mathrm{pg} / \mathrm{ml}$ and $25-\mathrm{OHD}_{3}$ at $20 \mathrm{ng} / \mathrm{ml}$ stimulate the rate of incorporation of $\left[{ }^{3} \mathrm{H}\right]$ thymidine into DNA of explants from rachitic chicks (Fig. 2). This increase in rate of incorporation is characterized by an initial delay of $1.5 \mathrm{~h}$ and a maximum response at $3 \mathrm{~h}$ (Fig. 1).

Two other parameters of the explant response to the calciferols measured were the rate of ${ }^{45} \mathrm{Ca}$ and $\left[{ }^{32} \mathrm{P}\right]$ phosphate accumulation by the intestinal explants (Fig. 2 ). The rate of ${ }^{45} \mathrm{Ca}$ uptake was measured after a 4-min exposure to the isotope since this duration of incubation was demonstrated previously to best reflect the rate of $\mathrm{Ca}$ transport across the brush border (28). $3 \mathrm{~h}$ after the addition of either $1,25-\mathrm{OH})_{2} \mathrm{D}_{3}$ or $25-\mathrm{OHD}_{3}$ to the cultures a linear dependence of the rate of ${ }^{45} \mathrm{Ca}$ uptake on the log of the sterol concentration could be demonstrated. The rate of $\left.{ }^{32} \mathrm{P}\right]$ phosphate uptake was studied after a 16-min exposure to the $\left.{ }^{32} \mathrm{P}\right]$ phosphate containing medium. As seen in Fig. 3, this time point approximates the first demonstrable inflection in the rate of ${ }^{32} \mathrm{P}$ accumulation by the explants as either free or organically bound phosphate and therefore could reflect the rate of phosphate transport across the brush border of the intestinal mucosa. This interpretation is supported by the ability of dinitrophenol and ouabain to inhibit this process. In addition, dinitrophenol inhibits the organification of phosphate whereas ouabain inhibits primarily the accumulation of ${ }^{32} \mathrm{P}$ as inorganic phosphate (Table $\mathrm{I}$ ). After $8 \mathrm{~min}$ of incubation in the isotope, determination of the distribution ratio of the inorganic ${ }^{32} \mathrm{P}$-phosphate as described by Rosenberg et al. (29) and defined as the ratio of radioactivity per milliliter of cell water and radioactivity per milliliter of incubation medium, indicates a value greater than 1.0 reaching $3.8 \pm 0.4$ at $16 \mathrm{~min}$ in explants from vitamin D-repleted chicks. In contrast, a distribution ratio of 1.8 \pm 0.2 was achieved in explants from rachitic chicks after $1 \mathrm{~h}$ of incubation and $16 \mathrm{~min}$ of exposure to the tracer. The ability of the explants to concentrate phosphate against a concentration gradient, as reflected by the distribution ratio determined at $16 \mathrm{~min}$ of exposure to the isotope was $1.7 \pm 0.1$ and $1.6 \pm 0.1$ after 4 and $6 \mathrm{~h}$, respectively, of incubation. Addition of either 1,25$(\mathrm{OH})_{2} \mathrm{D}_{3}$ at concentrations of $50 \mathrm{pg} / \mathrm{ml}$ and greater or $25-\mathrm{OHD}_{3}$ at concentrations of $20 \mathrm{ng} / \mathrm{ml}$ and greater

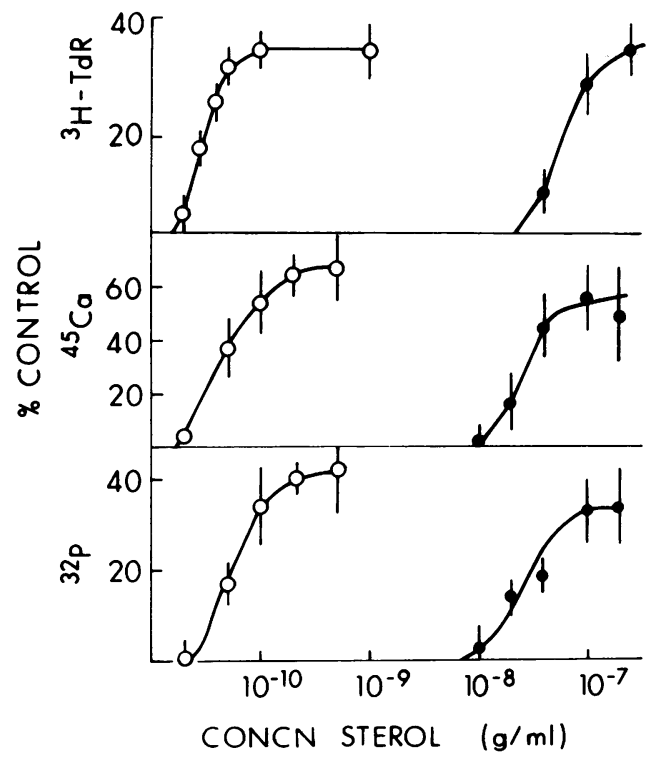

Figure 2 The dose-dependent response of vitamin Ddeficient chick intestinal explants to $1,25-(\mathrm{OH})_{2} \mathrm{D}_{3}$ (open circles) and $25-\mathrm{OHD}_{3}$ (closed circles). The data are expressed as the percent change from paired incubations in the absence of the sterols. The cumulative $\left[{ }^{3} \mathrm{H}\right]$ thymidine $\left({ }^{3} \mathrm{H}\right.$ TdR) incorporation into DNA was measured after $1.5 \mathrm{~h}$ of preincubation with the label, and $3 \mathrm{~h}$ after the addition of the sterol. The initial rate of ${ }^{45} \mathrm{Ca}$ uptake was determined at $3 \mathrm{~h}$ of incubation. The initial rate of $\left[{ }^{32} \mathrm{P}\right]$ phosphate accumulation was determined at $1.5 \mathrm{~h}$ of incubation. The vertical bars indicate the standard error of the mean. 


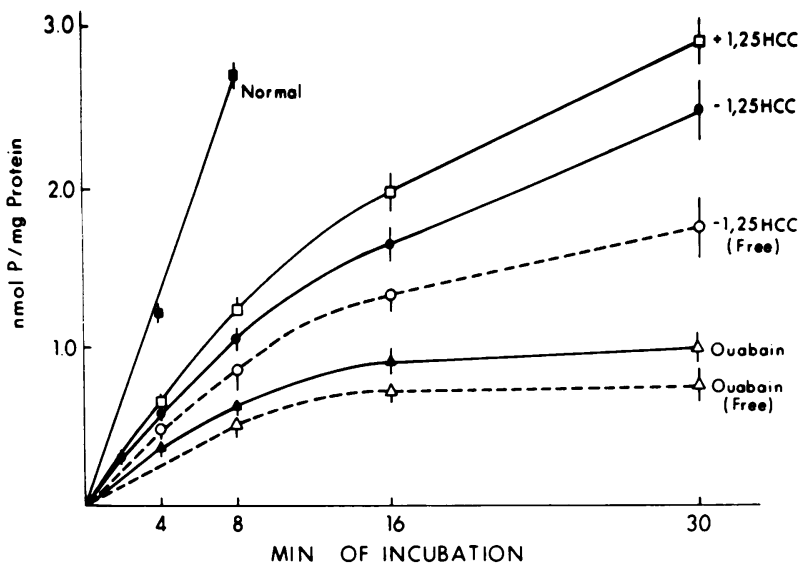

FIgURE 3 The kinetics of $\left[{ }^{32} \mathrm{P}\right]$ phosphate accumulation by chick intestinal explants. Chicks were maintained on a vitamin D-deficient diet or the same diet supplemented with vitamin $D$ for $3 \mathrm{wk}$. The explants were incubated for $90 \mathrm{~min}$ in the presence or absence of $1,25-(\mathrm{OH})_{2} \mathrm{D}_{3}(60 \mathrm{pg} / \mathrm{ml})$ before the determination of $\left[{ }^{32} \mathrm{P}\right]$ phosphate accumulation. The uptake of ${ }^{32} \mathrm{P}$ in the presence of ouabain $(1 \mathrm{mM})$ followed an 8-min preincubation with the inhibitor. The solid lines indicate the total $\left[{ }^{32} \mathrm{P}\right]$ phosphate accumulation per mg protein. The interrupted lines indicate the accumulation of "free" inorganic phosphate. The vertical bars indicate the standard error of the means.

stimulates $\left[{ }^{32} \mathrm{P}\right]$ phosphate accumulation without significantly altering the ratio between the inorganic and organic fractions. Cholecalciferol at concentrations as high as $1 \mu \mathrm{g} / \mathrm{ml}$ was without effect. The rate of accumulation of inorganic phosphate was examined as a function of the incubation medium inorganic phosphate concentration. A double reciprocal plot of these data suggests that two saturable transport mechanisms for inorganic phosphate may be operating (Fig. 4). A low affinity transport mechanism $\left(K_{m}=0.125 \mathrm{mM}\right)$ appears to respond to $1,25-(\mathrm{OH})_{2} \mathrm{D}_{3}$ with an increase in $V_{\text {max }}$ of the transport process whereas the sterol does not appear to alter the $V_{\max }$ of the high affinity $\left(K_{m}\right.$ $=0.0047 \mathrm{mM}$ ) transport mechanism.

The role of transcription and translation in mediating the mucosal response to $1,25-(\mathrm{OH})_{2} \mathrm{D}_{3}$ was examined by observing the influence of actinomycin and cycloheximide on the explant response to $1,25-(\mathrm{OH})_{2} \mathrm{D}_{3}$. The explants were preincubated for $20 \mathrm{~min}$ in the presence of $5.0 \mu \mathrm{g} / \mathrm{ml}$ of actinomycin D before the addition of the sterol. The explants were then incubated for an additional $3 \mathrm{~h}$ in the presence of $1,25-(\mathrm{OH})_{2} \mathrm{D}_{3}$ and actinomycin $\mathrm{D}$ before determining the rate of ${ }^{45} \mathrm{Ca}$ uptake. At an actinomycin D concentration of $0.5 \mu \mathrm{g} / \mathrm{ml}$, $\left[{ }^{3} \mathrm{H}\right]$ uridine incorporation into RNA was $18 \%$ of the control rate of incorporation for the last $2 \mathrm{~h}$ of the incubation. Actinomycin D did not block the vitamin-induced increase in the rate of ${ }^{45} \mathrm{Ca}$ uptake by the explants (Table II). To the contrary, actinomycin D stimu-
TABLE I

The Influence of Ouabain and Dinitrophenol on the Accumulation and Distribution of $\left[{ }^{32} \mathrm{P}\right]$ Phosphate by Intestinal Explants

\begin{tabular}{lccc}
\hline $\begin{array}{c}\text { Experimental } \\
\text { conditions }\end{array}$ & Total ${ }^{32} \mathrm{P}$ & Inorganic ${ }^{32} \mathrm{P}$ & $P$ value \\
\hline & $\begin{array}{c}\% \text { control } \\
\pm S E M\end{array}$ & $\begin{array}{c}\% \text { total }{ }^{32} \mathrm{P} \\
\pm S E M\end{array}$ & \\
& 100 & $81.8 \pm 1.8$ & \\
Control & & & \\
$+1,25-(\mathrm{OH})_{2} \mathrm{D}_{3}$ & $165 \pm 6$ & $84.5 \pm 2.1$ & $<0.1$ \\
$\quad(200 \mathrm{pg} / \mathrm{ml})$ & $54 \pm 3$ & $76.0 \pm 3.5$ & $<0.05$ \\
Ouabain $(0.1 \mathrm{mM})$ & $68 \pm 5$ & $98.2 \pm 4.1$ & $<0.01$ \\
DNP $(0.5 \mathrm{mM})$ & & & \\
\hline
\end{tabular}

Accumulation of $\left[{ }^{32} \mathrm{P}\right]$ phosphate $\left({ }^{32} \mathrm{P}\right)$ was measured after a 1.5-h incubation with or without $1,25-(\mathrm{OH})_{2} \mathrm{D}_{3}$ and expressed as a percentage of control incubations. To determine the rate of ${ }^{32} \mathrm{P}$ uptake in the presence of the inhibitor, the explants were preincubated for $8 \mathrm{~min}$ with the respective inhibitor. The inorganic ${ }^{32} \mathrm{P}$ accumulated is expressed as a percentage of the total ${ }^{32} \mathrm{P}$ accumulated per milligram protein in $16 \mathrm{~min}$. Student's $t$ test was applied to the analysis of paired data. The $P$ values apply to the differences from control of the percentage of inorganic ${ }^{32} \mathrm{P}$ of total ${ }^{32} \mathrm{P}$.

lated control ${ }^{45} \mathrm{Ca}$ uptake and potentiated the 1,25$(\mathrm{OH})_{2} \mathrm{D}_{3}$-stimulated ${ }^{45} \mathrm{Ca}$ uptake. The requirement for protein synthesis in mediating the response to 1,25 $(\mathrm{OH})_{2} \mathrm{D}_{3}$ was studied by measuring the rate of ${ }^{45} \mathrm{Ca}$ uptake after $3 \mathrm{~h}$ of incubation of the explants in the presence of the vitamin and cycloheximide at $50 \mu \mathrm{g} /$ $\mathrm{ml}$. After a similar protocol, the rate of $\left[{ }^{32} \mathrm{P}\right]$ phosphate accumulation was measured after $90 \mathrm{~min}$ of incuba-

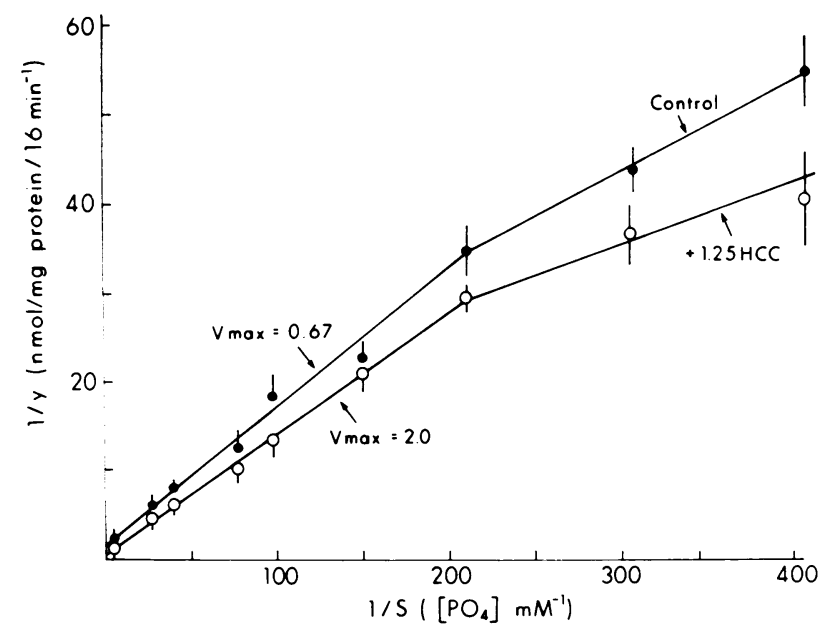

Figure 4 Double reciprocal plot of the concentration of phosphate $(1 / \mathrm{s})$ and the rate of accumulation of phosphate per milligram protein per $16 \mathrm{~min}(1 / \mathrm{y})$. The rate of accumulation was determined after $1.5 \mathrm{~h}$ of incubation in the presence or absence of $1,25-(\mathrm{OH})_{2} \mathrm{D}_{3}(60 \mathrm{pg} / \mathrm{ml})$. The vertical bars indicate the standard error of the mean. 
TABLE II

Influence of Actinomycin D (5 $\mathrm{\mu g} / \mathrm{ml})$ on the Mucosal Response to $1,25-(\mathrm{OH})_{2} \mathrm{D}_{3}(50 \mathrm{pg} / \mathrm{ml})$

\begin{tabular}{lcc}
\hline \multicolumn{1}{c}{ Experimental group } & $\begin{array}{c}\text { Percent of } \\
\text { control }\end{array}$ & $P$ value \\
\hline & $\%$ & \\
Control & 100 & \\
$+1,25-(\mathrm{OH})_{2} \mathrm{D}_{3}$ & $145 \pm 8$ & $<0.01$ \\
+ Actinomycin D & $146 \pm 6$ & $<0.01$ \\
$+1,25-(\mathrm{OH})_{2} \mathrm{D}_{3}+$ actinomycin $\mathrm{D}$ & $190 \pm 10$ & $<0.001$ \\
No. of observations & & 14
\end{tabular}

Chick intestinal explants were incubated for $20 \mathrm{~min}$ in medium with or without $50 \mu \mathrm{g} / \mathrm{ml}$ of actinomycin D before transfer to medium with or without $1,25-(\mathrm{OH})_{2} \mathrm{D}_{3}(60 \mathrm{pg} / \mathrm{ml})$ for an additional $3 \mathrm{~h}$. The initial rate of ${ }^{45} \mathrm{Ca}$ uptake per milligram protein is expressed as a percentage of the uptake by control explants incubated without actinomycin D and 1,25$(\mathrm{OH})_{2} \mathrm{D}_{3}$. Statistical significance was determined from a $t$ test of paired data analysis.

tion in the presence of the $1,25-(\mathrm{OH})_{2} \mathrm{D}_{3}$. Cycloheximide blocked both the $1,25-(\mathrm{OH})_{2} \mathrm{D}_{3}$-induced increased rate of $\left[{ }^{32} \mathrm{P}\right]$ phosphate accumulation and also the $1,25-(\mathrm{OH})_{2} \mathrm{D}_{3}$-induced increased rate of ${ }^{45} \mathrm{Ca}$ uptake (Table III).

The time course of the mucosal response to the vitamin D metabolites indicates that at $30 \mathrm{~min}$ after the addition of the sterols to the medium, the rate of $\left[{ }^{32} \mathrm{P}\right]-$ phosphate accumulation by the explants is significantly enhanced $(P<0.025)$. This response precedes by 30 and $150 \mathrm{~min}$ the vitamin-induced stimulation of ${ }^{45} \mathrm{Ca}$ uptake and the stimulation of $\left[{ }^{3} \mathrm{H}\right]$ thymidine incorpora-

\section{TABLE III}

Influence of Cycloheximide on 1,25- $(\mathrm{OH})_{2} \mathrm{D}_{3}$-Induced Stimulation of ${ }^{32} \mathrm{P}$-Phosphate and ${ }^{45} \mathrm{Ca}$ Uptake

\begin{tabular}{|c|c|c|c|c|c|}
\hline \multicolumn{2}{|c|}{ Culture conditions } & \multicolumn{2}{|c|}{${ }^{32} \mathrm{P}$ uptake } & \multicolumn{2}{|c|}{${ }^{45} \mathrm{Ca}$ uptake } \\
\hline Cyclo. & $1,25-(\mathrm{OH})_{2} \mathrm{D}_{3}$ & $\begin{array}{l}\text { Control } \\
\pm \text { SEM }\end{array}$ & $P$ value & $\begin{array}{l}\text { Control } \\
\pm \text { SEM }\end{array}$ & $P$ value \\
\hline & & $\%$ & & $\%$ & \\
\hline - & - & 100 & & 100 & \\
\hline+ & - & $110 \pm 3$ & $>0.1$ & $138 \pm 15$ & $<0.05$ \\
\hline- & + & $165 \pm 8$ & $<0.001$ & $170 \pm 10$ & $<0.01$ \\
\hline+ & + & $100 \pm 6$ & $>0.1$ & $146 \pm 9$ & $<0.05$ \\
\hline \multicolumn{3}{|c|}{ No paired observations } & & \multicolumn{2}{|c|}{5} \\
\hline
\end{tabular}

Chick intestinal explants were incubated for $20 \mathrm{~min}$ in medium with or without cycloheximide (Cyclo.) before transfer to medium with or without $1,25-(\mathrm{OH})_{2} \mathrm{D}_{3}(200 \mathrm{pg} / \mathrm{ml})$ for $3 \mathrm{~h}$. The data indicate the uptake of $\left.{ }^{32} \mathrm{P}\right]$ phosphate in $16 \mathrm{~min}$ or the uptake of ${ }^{45} \mathrm{Ca}$ in 4 min per milligram protein expressed as the mean percentage change from control incubations. Statistical significance was determined from a $t$ test of paired data analysis.

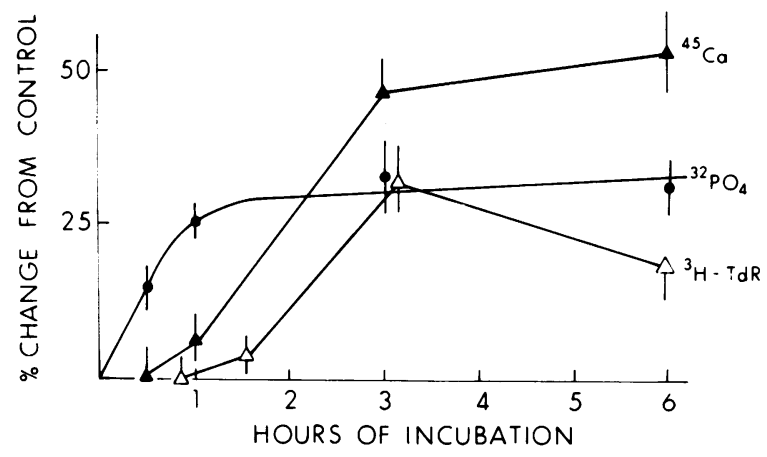

FIGURE 5 The response of explants from vitamin D-deficient chicks to $1,25-(\mathrm{OH})_{2} \mathrm{D}_{3}$. The measured radioactivity (dpm) per milligram protein or DNA is expressed as a percent change from control explants incubated without $1,25-(\mathrm{OH})_{2} \mathrm{D}_{3}$. Closed circles indicate the accumulation of $\left[{ }^{32} \mathrm{P}\right]$ phosphate, the closed triangles indicate the rate of ${ }^{45} \mathrm{Ca}$ uptake, and the open triangles indicate the cumulative rate of $\left[{ }^{3} \mathrm{H}\right]$ thymidine incorporation into DNA. The vertical bars indicate the standard error of the mean.

tion into DNA (Fig. 5). Thus the initial action of the vitamin is the stimulation of the rate of intracellular phosphorus accumulation. To test the hypothesis that the increased rate of ${ }^{45} \mathrm{Ca}$ uptake and DNA synthesis are secondary to an increased intracellular inorganic phosphate concentration, the influence of extracellular phosphate concentration on these parameters and the mucosal response to $1,25-(\mathrm{OH})_{2} \mathrm{D}_{3}$ was studied. Increasing medium phosphate concentration from 0.5 to $3.0 \mathrm{mM}$ for the 4.5-h duration of incubation increased $\left[{ }^{3} \mathrm{H}\right]$ thymidine incorporation into DNA (Table IV). Preincubation of the rachitic chick ileum explants in $3.0 \mathrm{mM}$ phosphate for $3.0 \mathrm{~h}$ increased the initial rate of ${ }^{45} \mathrm{Ca}$ uptake from $0.5 \mathrm{mM}$ phosphate buffer compared to ${ }^{45} \mathrm{Ca}$ uptake by explants preincubated at 0.5 $\mathrm{mM}$ phosphate for $3.0 \mathrm{~h}$ (Fig. 6). The increase in $\left[{ }^{3} \mathrm{H}\right]-$ thymidine incorporation into DNA and ${ }^{45} \mathrm{Ca}$ uptake achieved by equilibrating the explants in $3.0 \mathrm{mM}$ phosphate medium was equivalent to that observed in explants incubated with $1,25-(\mathrm{OH})_{2} \mathrm{D}_{3}$ at $0.5 \mathrm{mM}$ phosphate. No additional stimulation of either parameter was obtained with $1,25-(\mathrm{OH})_{2} \mathrm{D}_{3}$ in explants incubated in $3.0 \mathrm{mM}$ phosphate. Reducing the 3-h preincubation phosphate concentration from 0.5 to $0.05 \mathrm{mM}$ significantly reduced the rate of ${ }^{45} \mathrm{Ca}$ uptake as well as the response to $1,25-(\mathrm{OH})_{2} \mathrm{D}_{3}$. Since $1,25-(\mathrm{OH})_{2} \mathrm{D}_{3}$ stimulation of ${ }^{45} \mathrm{Ca}$ uptake can be inhibited by iodoacetamide, the influence of this inhibitor on the high phosphateinduced stimulation of ${ }^{45} \mathrm{Ca}$ uptake was examined. At least $50 \%$ of the phosphate-induced stimulation of ${ }^{45} \mathrm{Ca}$ uptake was inhibited by $0.05 \mathrm{mM}$ iodoacetamide (Table V).

The influence of phosphate on mucosal-serosal transport of $\mathrm{Ca}$ was measured in everted gut sacs obtained from rats maintained for $4 \mathrm{wk}$ on a $0.1 \%$ phosphorus, 
TABLE IV

Effect of Phosphorus and 1,25- $(\mathrm{OH})_{2} \mathrm{D}_{3}$ on ${ }^{3} \mathrm{H}-\mathrm{T} d \mathrm{R}$ Incorporation into DNA

\begin{tabular}{cccc}
\hline \multicolumn{2}{c}{ Culture conditions } & & \\
\hline $\mathrm{PO}_{4}$ concn. & $1,25-(\mathrm{OH})_{2} \mathrm{D}_{3}$ & ${ }^{3} \mathrm{H}-\mathrm{dpm} / \mu \mathrm{g} \mathrm{DNA}$ & $P$ value \\
\hline$m M$ & & $\pm S E M$ & \\
0.5 & - & $179 \pm 5$ & \\
0.5 & $60 \mathrm{pg} / \mathrm{ml}$ & $212 \pm 6$ & $<0.01$ \\
3.0 & - & $238 \pm 6$ & $<0.01$ \\
3.0 & $60 \mathrm{pg} / \mathrm{ml}$ & $225 \pm 7$ & $<0.01$ \\
\hline
\end{tabular}

Intestinal explants were incubated at either 0.5 or $3.0 \mathrm{mM}$ phosphate and $\left[{ }^{3} \mathrm{H}\right]$ thymidine $\left({ }^{3} \mathrm{H}-\mathrm{TdR}\right)$ for the duration of the study. After $1.5 \mathrm{~h}$ the explants were transferred to the same medium with or without $1,25-(\mathrm{OH})_{2} \mathrm{D}_{3}$. Statistical significance was determined from a $t$ test of paired data analysis.

$1.5 \% \mathrm{Ca}$, vitamin $\mathrm{D}$-free diet from the age of $3 \mathrm{wk}$ (Table VI). 4 days before sacrifice the animals were parathyroidectomized. 2 days before sacrifice the animals were divided into four groups. The first group was maintained on a $0.1 \% \mathrm{P}, 1.0 \% \mathrm{Ca}$ diet without vitamin $\mathrm{D}$. The second group of rats was placed on a $0.4 \% \mathrm{P}, 3.0 \% \mathrm{Ca}$ diet in an effort to abruptly increase the plasma phosphate and thereby minimizing the systemic effects of increased phosphate on the intestine. The third group of rats was maintained on $0.1 \%$ $\mathrm{P}, 1.0 \%$ Ca plus $200 \mathrm{U}$ of vitamin $\mathrm{D}_{3}$ orally $40 \mathrm{~h}$ before sacrifice. An increase in serum phosphorus was associated with an increase in the serosal:mucosal ratio of ${ }^{45} \mathrm{Ca}$ in the absence of vitamin D. Provision of phos-

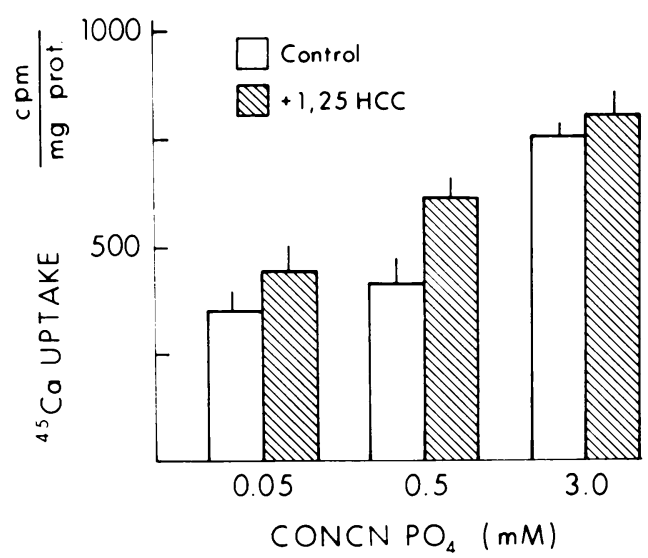

FIGURE 6 The influence of phosphate on ${ }^{45} \mathrm{Ca}$ uptake by intestinal explants. The initial rate of ${ }^{45} \mathrm{Ca}$ uptake was measured in the standard $0.5 \mathrm{mM}$ phosphate buffer after a 3-h preincubation in medium containing the designated concentration of phosphate. The open bars indicate incubations in the absence of $1,25-(\mathrm{OH})_{2} \mathrm{D}_{3}$ and the hatched bars indicate incubations in the presence of $1,25-(\mathrm{OH})_{2} \mathrm{D}_{3}$. The standard error of the mean is indicated by the vertical bars.
TABLE V

Influence of Iodoacetamide (IA) on 1,25-(OH $)_{2} D_{3}$-Induced and Phosphate-Induced Stimulation of ${ }^{45} \mathrm{Ca}$ Uptake

\begin{tabular}{cccccccc}
\hline & & & & \multicolumn{4}{c}{${ }^{45} \mathrm{Ca}$ uptake, (dpm/mg protein) } \\
\cline { 6 - 8 } PO $_{4}$ concn. & Culture conditions & & $\begin{array}{c}\text { Percent } \\
\text { control }\end{array}$ & $\begin{array}{c}\text { No. paired } \\
\text { observations }\end{array}$ & $P$ value \\
\hline$m M$ & & & & & $n$ & \\
0.5 & - & - & & 100 & & \\
0.5 & - & + & $113 \pm 3$ & 24 & $<0.05$ \\
0.5 & + & - & & $167 \pm 6$ & 13 & $<0.001$ \\
0.5 & + & + & $115 \pm 5$ & 13 & $<0.05$ \\
3.0 & - & - & $170 \pm 9$ & 11 & $<0.005$ \\
3.0 & - & + & $132 \pm 9$ & 11 & $<0.05$ \\
\hline
\end{tabular}

The explants were incubated for a total duration of $3.0 \mathrm{~h}$ under the conditions as noted. The initial rate of ${ }^{45} \mathrm{Ca}$ uptake was measured after the transfer of the explants to medium with or without iodoacetamide $(0.05 \mathrm{mM})$ and expressed as the mean percentage change from the control incubation. Statistical significance was determined from a $t$ test of paired data analysis.

phate and vitamin $\mathrm{D}$ to animals of the fourth group markedly enhanced the transport of Ca over that observed with the administration of vitamin $\mathrm{D}$ to animals on the phosphate-deficient diets.

\section{DISCUSSION}

Previous studies have demonstrated that vitamin D stimulates the proliferation of the intestinal mucosal epithelium $(18,30)$. Although an increase in cell number was not evident until $24 \mathrm{~h}$ after vitamin $\mathrm{D}$ administration, an increase in $\left[{ }^{3} \mathrm{H}\right]$ thymidine incorporation into intestinal mucosal DNA was observed at $4 \mathrm{~h}$ preceding

TABLE VI

Influence of Dietary Phosphate on the Intestinal Response to Vitamin D

\begin{tabular}{lcccc}
\hline \multicolumn{1}{c}{ Diet } & $-\mathrm{P}-\mathrm{D}$ & $+\mathrm{P}-\mathrm{D}$ & $-\mathrm{P}+\mathrm{D}$ & $+\mathrm{P}+\mathrm{D}$ \\
\hline$n$ & 15 & 15 & 18 & 13 \\
S/M ratio & $5.3 \pm 0.2$ & $5.9 \pm 0.2$ & $6.0 \pm 0.3$ & $7.4 \pm 0.4$ \\
$P$ value & & $<0.05$ & $<0.05$ & $<0.005$ \\
Ca serum, $\mathrm{mg} / 100 \mathrm{ml}$ & 11.8 & 11.1 & 11.6 & 11.8 \\
$\mathrm{P}$ serum, $\mathrm{mg} / 100 \mathrm{ml}$ & 3.7 & 5.0 & 4.7 & 6.5 \\
\hline
\end{tabular}

The serosal:mucosal ${ }^{45} \mathrm{Ca}$ concentration ratio (S/M) was measured in everted intestinal sacs from rats maintained for $4 \mathrm{wk}$ on a $0.1 \%$ phosphorus, $1.5 \% \mathrm{Ca}$, vitamin D-free diet. 4 days before sacrifice the animals were parathyroidectomized. 2 days before sacrifice the animals were divided into four dietary groups: (a) $0.1 \% \mathrm{P}$ and $1.0 \% \mathrm{Ca}(-\mathrm{P}-\mathrm{D})$, (b) $0.4 \% \mathrm{P}$ and $3.0 \%$ $\mathrm{Ca}(+\mathrm{P}-\mathrm{D})$, (c) $0.1 \% \mathrm{P}$ and $1.0 \% \mathrm{Ca}$ plus $200 \mathrm{U}$ of vitamin $\mathrm{D}$ orally $40 \mathrm{~h}$ before sacrifice $(-\mathrm{P}+\mathrm{D}),(\mathrm{d}) 0.4 \% \mathrm{P}$ and $2.0 \%$ Ca plus vitamin $\mathrm{D}(+\mathrm{P}+\mathrm{D}) . n$ indicates the number of animals in each group. 
by $4-8 \mathrm{~h}$ a demonstrable increase in intestinal $\mathrm{Ca}$ absorption (18). It was postulated that the increase in cell proliferation was the consequence of a direct effect of the vitamin on intestinal epithelial cell and not secondary to systemic changes in mineral homeostasis. Maintenance of intestinal epithelium in organ culture facilitates the distinction between these two possible modes of vitamin D action in stimulating intestinal epithelial cell proliferation. Thus, the increase in $\left[{ }^{3} \mathrm{H}\right]$ thymidine incorporation into DNA observed in the present studies must be attributed to a direct effect of the vitamin on the cell. Although these findings are consistent with the stimulation of DNA synthesis by the vitamin, a reduction in endogenous thymidine generation or utilization without an increase in DNA synthesis cannot be excluded by these data.

The explants also demonstrated an increased rate of ${ }^{45} \mathrm{Ca}$ and $\left[{ }^{32} \mathrm{P}\right]$ phosphate accumulation in response to the addition of either $1,25-(\mathrm{OH})_{2} \mathrm{D}_{3}$ or $25-\mathrm{OHD}_{3}$. The intestinal response to physiologic concentrations of $25-\mathrm{OHD}_{3}$ is of great interest since this metabolite of vitamin $\mathrm{D}$ has been considered to be biologically inactive at these concentrations $(31,32)$. There is considerable evidence that the $1 \alpha$-hydroxylation reaction occurs exclusively in kidney and that further metabolism of $25-\mathrm{OHD}_{3}$ by intestine to $1,25-(\mathrm{OH})_{2} \mathrm{D}_{3}$ or some other potent biologically active sterol does not occur (33-35). Contamination of $25-\mathrm{OHD}_{3}$ with the biologically active isomer, 5,6-trans-25-hydroxycholecalciferol, is possible. However the potency of this sterol is comparable to that of $25-\mathrm{OHD}_{3}$ and therefore could not account for the observed response $(36,37)$. The presence in intestinal mucosa, as well as in essentially all other tissues, of a cytoplasmic protein with high affinity and specificity for $25-\mathrm{OHD}_{2}(15,16)$ is additional evidence that this sterol may play a significant role in normal cell metabolism.

Earlier studies in rats (28) and confirmed in chick explants suggest that the initial rate of ${ }^{45} \mathrm{Ca}$ entry into the mucosa reflects the energy-dependent transport of $\mathrm{Ca}$ across the brush border into a readily saturable pool consistent with the cell cytosol Ca pool. The accumulation of phosphate has not been as extensively characterized. Saturation of an initial pool of $\left.{ }^{32} \mathrm{P}\right]$ phosphate does not appear to occur until 8-16 min. Distribution of tracer in cell water suggests an inorganic phosphate concentration comparable to that postulated for the cytoplasmic phosphate pool (31). The ability of metabolic inhibitors to block accumulation of intracellular phosphate suggests that the transport process is not only against a concentration gradient but does require metabolic energy. The increased rate of inorganic phosphate accumulation induced by the vitamin $D$ sterols is associated with a parallel increase in organic phosphate. This response is consistent with a primary action of the sterols on phosphate entry into the cell as opposed to increased utilization and further suggests that, in rachitic explants, phosphate entry may be rate limiting in a variety of processes resulting in organification of phosphate.

The mechanism of $1,25-(\mathrm{OH})_{2} \mathrm{D}_{3}$ and $25-\mathrm{OHD}_{3}$ action on phosphate entry across the brush border remains uncertain. It should be noted (Fig. 3) that the bulk of phosphate transported across the brush border is independent of vitamin D and occurs by two saturable processes. The $V_{\max }$ of the low affinity process appears to be increased from 0.67 to $2.0 \mathrm{nmol} / \mathrm{mg}$ protein $/ 16 \mathrm{~min}$ by $1,25-(\mathrm{OH})_{2} \mathrm{D}_{3}$ without significant alteration in $K_{m}$ of $0.125 \mathrm{mM}$. The increase in the rate of phosphate accumulation in response to the addition of $1,25-(\mathrm{OH})_{2} \mathrm{D}_{3}$ is blocked by incubation of the explants with cycloheximide. This inhibitor of protein synthesis at the level of translation also blocked the sterol-induced increase in ${ }^{45} \mathrm{Ca}$ uptake, suggesting that protein synthesis was required for the expression of the cells response to vitamin $\mathrm{D}$. However, actinomycin $\mathrm{D}$ at a concentration of $5.0 \mu \mathrm{g} / \mathrm{ml}, 10$ times the concentration necessary to inhibit $82 \%$ of $\left[{ }^{3} \mathrm{H}\right]$ uridine incorporation in RNA of the explants, did not block the vitamin's stimulation of ${ }^{45} \mathrm{Ca}$ uptake. To the contrary, actinomycin D stimulated ${ }^{45} \mathrm{Ca}$ uptake in the control explants and had an additive effect on ${ }^{45} \mathrm{Ca}$ uptake in the explants incubated in the presence of submaximal concentrations of $1,25-(\mathrm{OH})_{2} \mathrm{D}_{3}$. Additional studies are necessary to distinguish from the numerous interpretations of these findings that which correctly describes the observed data. The failure of actinomycin to inhibit the cellular response to $1,25-(\mathrm{OH})_{2} \mathrm{D}_{3}$ need not be interpreted as being inconsistent with the cycloheximide studies. The relatively short, 3-h incubation may not be sufficient to allow for the degradation of preexisting messenger-RNA from which the appropriate proteins can be synthesized for the expression of the mucosal response to $1,25-(\mathrm{OH})_{2} \mathrm{D}_{3}$. The vitamin may also stimulate translational events as has been postulated, in part, for the action of glucocorticoids $(38,39)$. These observations do suggest that de novo protein synthesis from a nuclear DNA template is not required for the initial manifestation of the cellular response to $1,25-(\mathrm{OH})_{2} \mathrm{D}_{3}$ as characterized by an increase in ${ }^{45} \mathrm{Ca}$ uptake and an increase in $\left[{ }^{32} \mathrm{P}\right]$ phosphate accumulation. Since the intestinal response to vitamin $D$ is biphasic, the delayed response, greater in magnitude, may reflect an increase in DNA template activity and messenger RNA.

In studying the time course of the explant response to the vitamin D sterols, it is apparent that the earliest response is the stimulation of $\left.{ }^{32} \mathrm{P}\right]$ phosphate accumulation which precedes the stimulation of ${ }^{45} \mathrm{Ca}$ uptake by $30 \mathrm{~min}$ and the increase in $\left[{ }^{3} \mathrm{H}\right]$ thymidine incorporation into DNA by $150 \mathrm{~min}$. This observation 
raised the possiblity that the latter two events were either dependent upon or secondary to a primary action of the vitamins on phosphate transport and presumably the restoration of intracellular phosphate pools. To test this hypothesis, an effort was made to increase intracellular phosphate concentrations in the absence of vitamin $D$ sterols by passive diffusion. Accordingly extracellular phosphate concentration was increased to $3.0 \mathrm{mM}$. Both ${ }^{45} \mathrm{Ca}$ uptake and DNA synthesis were enhanced under these conditions. The increase in ${ }^{45} \mathrm{Ca}$ uptake resulting from the high extracellular phosphate concentration was inhibited by iodoacetamide, similar to the iodoacetamide inhibition of the $1,25-(\mathrm{OH})_{2} \mathrm{D}_{3}$ dependent increase in ${ }^{45} \mathrm{Ca}$ uptake. The failure of other investigators $(40)$ to demonstrate inhibition of 1,25 $(\mathrm{OH})_{2} \mathrm{D}_{3}$-stimulated ${ }^{45} \mathrm{Ca}$ uptake by iodoacetamide may be due to the fact that iodoacetamide at concentrations greater than $0.05 \mathrm{mM}$ increases the basal rate of ${ }^{45} \mathrm{Ca}$ uptake. Reduction of the extracellular phosphate concentration to $0.05 \mathrm{mM}$ resulted in a significant blunting of the intestinal response to 1,25$(\mathrm{OH})_{2} \mathrm{D}_{3}$ (Fig. 6). These observations suggest that intracellular phosphate concentration is an important determinant of the metabolically dependent transport of Ca across the brush border of the intestinal epithelial cell. These data extend earlier investigations concerning the facilitation by phosphate of calcium uptake in kidney cells (41) and calcium translocation in rat intestine (42). The failure of other investigators to observe a dependence of calcium translocation upon phosphate in vitamin D-deficient tissue may be attributed to the failure to alter intracellular phosphate concentrations as a result of short durations of incubation and low medium phosphate concentrations $(43,44)$.

The role of phosphate in mucosal-serosal transport of calcium was examined in the rat everted duodenal sac. The serum phosphorus of the phosphorusdepleted animal was raised abruptly over a 2-day period by the addition of phosphate or the treatment of the animal with oral vitamin $\mathrm{D}$, or both. More prolonged phosphate feeding was avoided so that the adaptive increase in calcium absorption attributed to phosphorus depletion would not be altered. All animals were parathyroidectomized to eliminate the potential influence of this hormone on the transport process. The increase in serum phosphorus was limited by the above constraints and the additional constraint of maintaining normal serum calcium concentrations. Despite the limited increase in extracellular phosphate concentrations, calcium transport was increased in the absence of vitamin D and maximal stimulation of calcium transport required increased dietary phosphate in addition to vitamin D treatment. Again these data suggest that the intestinal response to vitamin $\mathrm{D}$ is de- pendent, at least in part, upon the availability of phosphate. The initial rate of ${ }^{45} \mathrm{Ca}$ uptake studied in the intestinal explants may well reflect a rate limiting step in the mucosal-serosal transport of calcium in the rachitic animal. Intracellular phosphate concentration may influence directly or indirectly through a high energy phosphate intermediate, such as ATP, this step in the transport process. Thus, stimulation by vitamin $\mathrm{D}$ of intracellular phosphate accumulation and the restoration of intracellular phosphate concentrations towards normal may play an important if not primary role in the ultimate expression of the cells' response to the vitamin $\mathrm{D}$ sterols.

\section{REFERENCES}

1. Harrison, H. E., and H. C. Harrison. 1961. Intestinal transport of phosphate: action of vitamin $\mathrm{D}$, calcium and potassium. Am. J. Physiol. 201: 1007-1012.

2. Kowarski, S., and D. Schachter. 1969. Effects of vitamin D on phosphate transport and incorporation into mucosal constituents of rat intestinal mucosa. J. Biol. Chem. 244: 211-217.

3. Wasserman, R. H., and A. N. Taylor. 1973. Intestinal absorption of phosphate in the chick: effect of vitamin $\mathrm{D}_{3}$ and other parameters. J. Nutr. 103: 586-599.

4. Taylor, A. N. 1974. In vitro phosphate transport in chick ileum: effect of cholecalciferol, calcium, sodium and metabolic inhibitors. J. Nutr. 104: 489-494.

5. Chen, T. C., L. Castillo, M. Korycka-Dahl, and H. F. DeLuca. 1974. Role of vitamin D metabolites in phosphate transport of rat intestine. J. Nutr. 104: 1056-1060.

6. Walling, M. W., and D. V. Kimberg. 1975. Effect of $1 \alpha, 25-$ dihydroxyvitamin $\mathrm{D}_{3}$ and Solanum Glaucophyllum on intestinal calcium and phosphate transport and on plasma $\mathrm{Ca}, \mathrm{Mg}$ and $\mathrm{P}$ levels in the rat. Endocrinology. 97: $1567-1576$.

7. Raisz, L. G. 1970. Physiologic and pharmacologic regulation of bone resorption. N. Engl. J. Med. 282: 909-916.

8. Steele, T. H., J. E. Engle, Y. Tanaka, R. S. Lorenc, K. L. Dudgeon, and H. F. DeLuca. 1975. Phosphatemic action of 1,25-dihydroxy-vitamin $\mathrm{D}_{3}$. Am. J. Physiol. 229: $489-495$.

9. Puschett, J. B., W. S. Beck, Jr., and A. Jelonek. 1975. Parathyroid hormone and 25-hydroxyvitamin $\mathrm{D}_{3}$ : synergistic and antagonistic effects on renal phosphate transport. Science (Wash. D. C.). 190: 473-475.

10. Popovtzer, M. M., J. B. Robinett, H. F. DeLuca, and M. F. Holick. 1974. The acute effect of 25-hydroxycholecalciferol on renal handling of phosphorus. J. Clin. Invest. 53: 913-921.

11. Puschett, J. B., J. Moranz, and W. S. Kurnick. 1972. Evidence for a direct action of cholecalciferol and 25hydroxycholecalciferol on the renal transport of phosphate, sodium and calcium. J. Clin. Invest. 51: 373-383.

12. Hughes, M. R., P. F. Brumbaugh, M. R. Haussler, J. E. Wergedal, and D. J. Baylink. 1975. Regulation of serum $1 \alpha, 25$-dihydroxyvitamin $\mathrm{D}_{3}$ by calcium and phosphate in the rat. Science (Wash. D. C.). 190: 578-580.

13. Baxter, L. A., and H. F. DeLuca. 1976. Stimulation of 25hydroxyvitamin $\mathrm{D}_{3} l \alpha$-hydroxylase by phosphate depletion. J. Biol. Chem. 251: 3158-3161.

14. Steenbock, H., and D. C. Herting. 1955. Vitamin D and growth. J. Nutr. 57: 449-468. 
15. Haddad, J. G., and S. J. Birge. 1975. Widespread, specific binding of 25-hydroxycholecalciferol in rat tissues.J. Biol. Chem. 250: 299-303.

16. Lawson, D. E. M., M. Charman, P. W. Wilson, and S. Edelstein. 1976. Some characteristics of new tissuebinding proteins for metabolites of vitamin $D$ other than 1,25-dihydroxyvitamin D. Biochim. Biophys. Acta. 437: 403-415.

17. Birge, S. J., and J. G. Haddad. 1975. 25-hydroxycholecalciferol stimulation of muscle metabolism. J. Clin. Invest. 56: 1100-1107.

18. Birge, S. J., and D. H. Alpers. 1973. Stimulation of intestinal mucosal proliferation by vitamin D. Gastroenterology. 64: 977-982.

19. Boyle, I. T., L. Miravet, R. W. Gray, M. F. Holick, and H. F. DeLuca. 1972. The response of intestinal calcium transport to 25-hydroxy and 1,25-dihydroxyvitamin D in nephrectomized rats. Endocrinology. 90: 605-608.

20. Cerriotti, G. 1952. A microchemical determination of deoxyribonucleic acid. J. Biol. Chem. 198: 297-303.

21. Keck, K. 1956. An ultra micro technique for the determination of deoxypentosenucleic acid. Arch. Biochem. Biophys. 63: 446-451.

22. Bonting, S. L., and M. Jones. 1957. Determination of microgram quantites of deoxyribonucleic acid and protein in tissue grown in vitro. Arch. Biochem. Biophys. 66: 340-353.

23. Munro, H. N., and A. Fleck. 1966. Recent developments in the measurement of nucleic acids in biological materials. Analyst. 91: 78-87.

24. Fleck, A., and D. J. Begg. 1965. The estimation of ribonucleic acid using ultraviolet absorption measurements. Biochim. Biophys. Acta. 108: 333-339.

25. Lipmann, F., and L. C. Tuttle. 1944. Acetyl phosphate: Chemistry, determination and synthesis. J. Biol. Chem. 153: 571-582.

26. Short, E. M., H. J. Binder, and L. E. Rosenberg. 1973. Familial hypophosphatemic rickets: defective transport in inorganic phosphate by intestinal mucosa. Science (Wash. D. C.). 179: 700-702.

27. Lowry, O. H., N. J. Rosebrough, A. L. Farr, and R. J. Randall. 1951. Protein measurement with the Folin phenol reagent. J. Biol. Chem. 193: 265-275.

28. Birge, S. J., S. C. Switzer, and D. R. Leonard. 1974. Influence of sodium and parathyroid hormone on calcium release from intestinal mucosal cells. J. Clin. Invest. 54: 702-709.

29. Rosenberg, L. E., S. Downing, J. Durant, and S. Segal. 1966. Cystinuria-biochemical evidence for three genetically distinct diseases. J. Clin. Invest. 45: 365-371.

30. Spielvogel, A. M., R. D. Farley, and A. W. Norman. 1972. Studies on the mechanism of action of calciferol. V. Turn- over time of chick intestinal epithelial cells in relation to the intestinal action of vitamin D. Exp. Cell Res. 74: 359366.

31. DeLuca, H. F., and H. K. Schnoes. 1976. Metabolism and mechanism of action of vitamin D. Annu. Rev. Biochem. 45: 631-666.

32. Wong, R. G., A. W. Norman, C. R. Reddy, and J. W. Coburn. 1972. Biological effects of 1,25-dihydroxycholecalciferol (a highly active vitamin D metabolite) in acutely uremic rats. J. Clin. Invest. 51: 1287-1291.

33. Fraser, D. R. and E. Kodicek. 1970. Unique biosynthesis by kidney of a biologically active vitamin $\mathrm{D}$ metabolite. Nature (Lond.). 228: 764-766.

34. Norman, A. W., R. J. Midget, J. F. Myrtle, and H. G. Nowicki. 1971. Studies on calciferol metabolism. I. Production of vitamin D metabolite 4B from 25-OH-cholecalciferol by kidney homogenates. Biochem. Biophys. Res. Commun. 42: 1082-1087.

35. Gray, R., I. Boyle, and H. F. DeLuca. 1971. Vitamin D metabolism: the role of kidney tissue. Science (Wash. D. C.). 172: 1232-1234.

36. Holick, M. F., M. Garabedian, and H. F. DeLuca. 1972. 5,6-Trans-25-hydroxycholecalciferol: vitamin D analog effective on intestine of anephric rats. Science (Wash. D. C.). 176: $1247-1248$.

37. Rutherford, W. E., K. Hruska, J. Blondin, M. Holick, H. F. DeLuca, S. Klahr, and E. Slatopolsky. 1975. The effect of 5,6-trans vitamin $\mathrm{D}_{3}$ on calcium absorption in chronic renal disease. J. Clin. Endocrinol. Metab. 40: 1318.

38. Kulkarni, S. B., M. S. Netrawali, D. S. Pradhan, and A. Sreenivasan. 1976. Action of hydrocortisone at a translational level in the rat liver. Mol. Cell. Endocrinol. 4: 195-203.

39. Cox, R. F., and A. P. Mathias. 1969. Cytoplasmic effects of cortisol in liver. Biochem. J. 115: 777-787.

40. Freund, T., and F. Bronner. 1975. Stimulation in vitro by 1,25-dihydroxyvitamin $D_{3}$ of intestinal cell calcium uptake and calcium-binding protein. Science (Wash. D. C.). 190: 1300-1301.

41. Borle, A. B. 1970. Kinetic analyses of calcium movements in cell cultures. IV. Effects of phosphate and parathyroid hormone in kidney cells. Endocrinology. 86: 1389-1393.

42. Helbock, H. J., J. G. Forte, and P. Saltman. 1966. The mechanism of calcium transport by rat intestine. Biochim. Biophys. Acta. 126: 81-93.

43. Martin, D. L., and H. F. DeLuca. 1969. Calcium transport and the role of vitamin D. Arch. Biochem. Biophys. 134: $139-148$.

44. Adams, T. H., and A. W. Norman. 1970. Studies on the mechanism of action of calciferol. J. Biol. Chem. 245: 4421-4431. 